\title{
PENYEBARAN HAMA KEPINDING TANAH DAN MUSUH ALAMINYA PADA PERTANAMAN PADI SAWAH DI SULAWESI UTARA
}

\section{DISTRIBUTION AND NATURAL ENEMIES OF PEST BEDBUG ON PADDY FIELD IN NORTH SULAWESI}

\author{
Evi Paendong ${ }^{1)}$, Jantje Pelealu²) dan Jimmy Rimbing ${ }^{2)}$ \\ 1) Staf Dosen Fakultas MIPA, Universitas Negeri Gorontalo \\ 2) Jurusan Hama dan Penyakit Tumbuhan Fakultas Pertanian, Universitas Sam Ratulangi Manado-95115
}

\begin{abstract}
Bedbug is the major pest in paddy fields in North Sulawesi. The pest attacks on vegetative and generative phase of rice. The species of pest attacking on paddy fields in North Sulawesi is unknown. The study aimed to evaluate the spread of bedbug ground pests, to identify the pest species as well as natural enemies of the pest at the ecosystem of paddy fields in North Sulawesi. The result showed that the pest had spread to paddy field in Bolaang Mongondow, South Minahasa and Southeast Minahasa. In Minahasa regency, the pest had not been detected. In terms of population density of pest bugs , the highest was found in Bolaang Mongondow which was 14.67 individual per 20 times of swinging followed by South Minahasa which was 10.33 individual. The lowest was found in Southeastern Minahasa which was 0.67 individuals. There were eight types of natural enemies of the pest in soil ecosystem of paddy fields in North Sulawesi. The eight types of natural enemies of the pest were seven predator and one parasitoid. The one parasitoid was Telenomus sp. The seven predator were Micraspis crocea, Methioche sp, Anaxipha sp, Oxyopes javanus, Tetragnatha sp, Lycosa sp and Chilomenes sp.
\end{abstract}

Keywords: bedbug spread of soil, its natural enemies

\section{ABSTRAK}

Hama kepinding tanah, Scotinpohara sp merupakan hama utama pada tanaman padi sawah di Sulawesi Utara, menyerang pada fase vegetatif dan generatif. Belum diketahui species kepinding tanah yang menyerang tanaman padi sawah di Sulawesi Utara. Penelitian bertujuan mengetahui penyebaran hama kepinding tanah, jenisnya dan musuh-musuh alami pada ekosistem tanaman padi sawah di Sulawesi Utara. Hasil penelitian menunjukkan bahwa kepinding tanah menyebar pada tanaman padi sawah di dataran rendah yakni Kabupaten Bolaang Mongondow, Minahasa Selatan, dan Minahasa Tenggara. Sedangkan pada daerah dataran tinggi yakni Kabupaten Minahasa belum ditemukan hama kepinding. Dari segi kepadatan populasi hama kepinding tertinggi ditemukan di Kabupaten Bolaang Mongondow 14,67 individu per 20 kali ayunan, kemudian diikuti Minahasa Selatan 10,33 inividu per 20 kali ayunan, dan terendah ditemukan di Minahasa tenggara 0,67 individu per 20 kali ayunan. Terdapat 8 jenis musuh-musuh alami hama kepinding tanah pada ekosistem tanaman padi sawah di Sulawesi Utara. Dari 8 jenis musuh-musuh alami yang ditemukan terdiri dari 1 jenis prasitoid dan 7 predator. Jenis parasitoid yang ditemukan adalah Telenomus sp, sedangkan untuk predator yakni Micraspis crocea, Methioche sp, Anaxipha sp Tetragnatha sp Oxyopes javanus, Lycosa sp, dan Chilomenes sp Kata kunci: Penyebaran kepinding tanah, musuh alaminya 


\section{PENDAHULUAN}

Beras masih merupakan sumber bahan makanan pokok bagi sebagian besar penduduk Indonesia. Hal ini menjadikan kebutuhan beras nasional setiap tahunnya semakin meningkat seiring bertambahnya jumlah penduduk. Indonesia mengimport beras pada tahun 2011 dari Vietnam dan India sebanyak 1,5 juta ton untuk kebutuhan akan penduduk Indonesia (Anonim, 2011). Adanya impor beras karena kebutuhan nasional tidak mencukupi akan kebutuhan penduduk Indonesia. Upaya meningkatkan produksi tanaman padi sawah di Indonesia diperhadapkan berbagai masalah yakni faktor abiotik dan biotik. Faktor abiotik yang terpenting berupa kemuduran kesuburan tanah, kekeringan, kondisi iklim dan cuaca. Sedangkan faktor biotik berupa organisme pengganggu tanaman, yaitu hama, penyakit dan gulma (Kartohardjono, $d k k ., 2008)$.

Organisme pengganggu tanaman yang cukup penting menyerang tanaman padi sawah adalah hama kepinding tanah, Scotinophara sp. Sembel, dkk. (2000) melaporkan bahwa serangga hama yang menyerang tanaman padi sawah di Sulawesi Utara sebanyak 22 jenis dan tidak termasuk hama kepinding tanah. Hama kepinding muncul pada pertanaman padi sawah di Sulawesi Utara sekitar tahun 2006. Kalshoven (1981) mengemukakan bahwa hama Scotinophara sp merupakan salah satu hama tanaman padi sawah yang cukup penting dan menyebar pada pertanaman padi sawah di Sulawesi, Sumatera, Kalimatan, dan Jawa. Serangan hama Scotinophara sp. menghisap cairan batang padi sawah sehingga menyebabkan tanaman menjadi kerdil, daunya menguning dan akhirnya mati. Serangga hama ini sangat merugikan dan dapat menyerang tanaman padi sawah di persamaian dan tanaman muda serta tanaman yang sudah berumur tua (Soemartono, dkk., 1984; dan Anonim, 2009). Kepinding tanah menjadi hama utama tanaman padi di daerah-daerah sawah pasang surut yang kondisinya selalu tergenang air, dengan kelembaban tinggi dan terlebih pada musim hujan (Kartohardjono, $d k k ., 2008)$.

Di Indonesia terdapat beberapa jenis hama Scotinophara sp. yang menyerang tanaman pa- di sawah, yakni Scotinophara coarctata, S lurida., dan $S$ vermiculata (Baehaki, 1992; Harahap dan Tjahyono, 2003). Di Filipina, Scotinophara yang menyerang tanaman padi terdiri dari 3 jenis dengan daerah penyebaran berbeda masing-masing jenis. S. coarctata di Palawan, S. Iurida di Mindanou, dan S. latiuscida di Luxon (Dale, 1994). Hama kepinding S. latiuscida menyerang pula tanaman padi sawah di Sumatera (Kalshoven, 1981). Dale (1994) melaporkan bahwa kepinding tanah terdiri dari 10 jenis yakni $S$. coarctata, S. lurida, S. inermiceps, $S$. obscura, S. latiusculla, S. bispinosa, S. Orcracea, $S$. parva, $S$ scotti dan $S$. scrrata. Torres et.al. (2010) melaporkan bahwa species Scotinophara terdiri dari 24 species pada ekosistem tanaman padi sawah. Di Benua Asia, kepinding tanah, $S$. coarctata merupakan hama penting di Asia yakni China, Taiwan, India, Malaysia, Philippines, Thailand dan Vitnam, sedangkan $S$. Iurida di Negara China, India, Japan dan Sri Langka (Anonim, 2009).

Serangga kepinding tanah termasuk jenis kepik berwarna hitam kusam dengan panjang berkisar antara 7-10 mm dan lebar kurang lebih $4 \mathrm{~mm}$. Siklus hidup kepinding berkisar antara 33-41 hari. Telur menetas setelah 7 hari. Betina bertelur pada 12-17 hari setelah kawin (Kalshoven, 1981; Kartohadjono, dkk., 2009). Telur diletakkan pada batang padi secara berkelompok sebanyak kurang lebih 30 butir per kelompok. Nimfa berwarna coklat kekuningan dengan bintik hitam dan tinggal pada pangkal tanaman padi pada siang hari dan makan serta mengisap tanaman pada malam hari. Serangga dewasa biasa hidup sampai 7 bulan (Anonim, 2010; Kartohardjono, dkk., 2009). Gejala kerusakan adalah di daerah sekitar lubang bekas hisapan berubah warna menjadi coklat menyerupai gejala penyakit blas. Daun menjadi kering dan menggulung secara membujur. Gejala seperti sundep dan beluk merupakan gejala kerusakan umum yang menyebabkan gabah setengah berisi atau hampa. (Anonim, 2005). Pengisapan oleh kepinding tanah pada fase anakan menyebabkan jumlah anakan berkurang dan pertumbuhan terhambat (kerdil). Apabila fase terjadi fase bunting, tanaman menghasilkan malai yang kerdil, exkresi malai yang tidak lengkap, dan gabah hampa. Dalam kondisis popu- 
lasi kepinding tinggi, tanaman yang dihisap dapat mati atau mengalami bugburn, seperti hopperburn oleh wereng coklat (Anonim, 2005).

Price (1983) mengemukakan bahwa jenis serangga hama, musuh alami kelimpahaan populasinya, dari satu tempat ke tempat yang lain berbeda. Hal ini disebabkan adanya perbedaan iklim, vegetasi, dan inang. Hama dan penyakit tanaman bersifat dinamis dan perkembangannya dipengaruhi oleh lingkungan biotik (fase pertumbuhan tanaman, adanya populasi organisme lain dan musuh alami) dan abiotik (iklim, musim dan agroekoesistem). Pada dasarnya semua organisme dalam keadaan seimbang jika tidak terganggu ekologiknya ekosistem tanaman.

Banyak cara untuk melakukan pengendalian terhadap serangga hama tanaman, namun pengendalian yang mempunyai prospek cukup baik dan tidak mencamari lingkungan adalah pemanfaatan musuh alami. Terdapat beberapa keuntungan penggunaan musuh alami diantaranya bersifat permanen, musuh alami dapat berkembang biak, sedangkan pestisida harus berulang-ulang kali melakukan penyemprotan untuk menurunkan populasi serangga hama. Debach (1964) mengemukakan bahwa pemanfaatan musuh-musuh alami sebagai agen hayati melalui pendekatan ciri morfologi, dan biologi. Musuh alami hama kepinding tanah, Scotinophara sp pada tanaman padi sawah, di antaranya Telenomus triptus, T. chloropus, Pssix lacunatus, Lycosa pseudoannulata, Oxyopes javnus, dan Micraspis crocea, Metarhixium anisopliae, dan Beauveria bassianan (Anonim, 2009). Jenis musuh alami tersebut belum pernah dilaporkan di Sulawesi Utara, oleh karena itu perlu diketahui jenis musuh alami hama kepinding untuk mengontrol populasi hama kepinding tanah. Demikian pula dalam melakukan koservasi musuh-musuh alami dari hama kepinding tidak mungkin dapat dilaksanakan bila belum diketahui mengenai jenis musuh alami hama kepinding tanah.

Bertolak dari uraian di atas, maka tujuan penelitian ini adalah mengetahui penyebaran hama kepinding tanah, jenis hama kepinding tanah dan musuh alaminya pada tanaman padi sawah di Sulawesi Utara.

\section{METODE PENELITIAN}

Penelitian ini telah dilaksanakan di daerah sentra produksi tanaman padi sawah di Sulawesi Utara, yaitu Kabupaten Minahasa, Kabupaten Minahasa Selatan, Kabupaten Bolaang Mongondow dan Kabupaten Minahasa Tenggara di Sulawesi Utara. Pelaksanaan penelitian selama 5 bulan.

\section{Pelaksanaan Penelitian}

Penelitian dilaksanakan di laboratorium dan lapangan. Penelitian laboratorium mengidentifikasi serangga hama kepinding tanah dan musuhmusuh alami (parasitoid dan predator). Penelitian lapangan adalah pengambilan contoh serangga hama kepinding tanah dan musuh alami.

\section{Penetapan Lokasi Pengambilan Data}

Pengambilan data tentang hama kepinding tanah, dan musuh alami dilakukan pada dua desa untuk satu wilayah kabupaten. Rincian sebagai lokasi pengambilan data adalah sebagai berikut: Kabupaten Minahasa di Desa Roong dan Koya, Kabupaten Minahasa Selatan di Desa Popontolen dan Matani, Kabupaten Bolaang Mongondow di Desa Nonapan dan Wineru, Kabupaten Minahasa Tenggara di Desa Wawali dan Rasi

\section{Pengambilan Contoh Serangga Hama Kepinding Tanah Scotinopharasp}

Pengambilan contoh serangga hama kepinding tanah, Scotinophara sp pada tanaman padi sawah dilakukan dengan jaring serangga. Untuk mendapatkan data hama kepinding tanah di setiap desa dilakukan pengambilan contoh hama kepinding dengan menggunakan jaring serangga. Masing-masing desa digunakan 2 petak tanaman padi sawah, kemudian dilakukan penyapuan dengan jaring serangga. Contoh serangga yang tertangkap dengan jaring serangga, kemudian dibawah ke laboratorium untuk keperluan identifikasi. Setiap petak dilakukan sebanyak 20 kali penyapuan dengan jaring serangga. Pengambilan contoh dilakukan sebanyak 3 kali, dengan interval waktu 2 minggu sekali pada tanaman padi berumur satu bulan. 


\section{Pengambilan Contoh Musuh Alami Pada Tanaman Padi}

Pengambilan contoh musuh alami bersamaan dengan pengambilan contoh hama kepinding tanah. Setiap tanaman target dilakukan pengambilan musuh alami sebanyak 3 kali, dengan interval waktu 2 minggu sekali. Musuh-musuh alami atau agen hayati yang tertangkap dengan jaring serangga dimasukkan ke dalam killing botol untuk dimatikan, selanjutnya dipilah-pilah sesuai dengan jenis dan kemudian diidentiifikasi di Laboratorium Entomologi dan Hama Tumbuhan Fakultas Pertanian Unsrat.

\section{Penetapan Serangga Hama dan Agen Hayati}

Serangga hama dan agen hayati atau musuh alami telah dikumpulkan dan diawetkan, kemudian dilakukan identifikasi. Identifikasi agen hayati dilakukan pada tingkat genus sampai spesies dengan menggunakan kunci agen hayati, sedangakan serangga hama identifikasi sampai tingkat spesies. Identifikasi dilakukan di Laboratorium Entomologi dan Hama Tumbuhan Fakultas Pertanian Unsrat berdasarkan ciri-ciri morfologis.

\section{HASIL DAN PEMBAHASAN}

\section{Hama Kepinding Tanah}

Hasil pengambilan contoh serangga dewasa kepinding tanah di lokasi penelitian dan kemudian dilakukan identifikasi di laboratorium menunjukkan bahwa hama kepinding tanah yang menyerang pada pertanaman padi sawah di Sulawesi Utara adalah $S$. coarctata. Jenis $S$. coarctata yang ditemukan pada pertanaman padi sawah terdapat pula di Malaysia dan Filipina (Catinding and Kong, 2007). Meskipun jenis $S$. coarctata yang ada di Sulawesi Utara sama dengan Malaysia dan Filipina, tetapi strain mungkin berbeda. Ukuran hama kepinding tanah dewasa untuk panjang kurang lebih 10 $\mathrm{mm}$, dan lebar $4 \mathrm{~mm}$.

Hama kepinding tanah yang ditemukan berwarna hitam kecoklatan, dengan spot berwarna kuning pada bagian thoraks dan abdomen, memiliki scutellum berbentuk huruf $U$, tungkai dan tibia berwarna kuning kemerahan, bagian scutellum terda- pat sebuah garis yang melengkung, dan scutellum tidak berambut. Pronotum pada $S$. coarctata agak membulat dan pada bagian anterior bersegi, dan ukuran pronotum lebih kecil dibandingkan dengan S. Iurida. Telur dari hama ini berwarna merah dan diletakkan secara berkelompok, dan telur berubah warna hitam pada saat telur akan menetas. Morfologi $S$. coarctata dan telur yang ditemukan di Sulawesi Utara dapat diikuti pada gambar 1.

\section{Penyebaran Hama Kepinding Tanah}

Hasil pengambilan contoh kepinding tanah, $S$. coartata di lapangan, menunjukkan bahwa hama kepinding tanah hampir menyebar merata pada pertanaman padi sawah di Sulawesi Utara, kecuali Kabupaten Minahasa. Wilayah yang ditemukan adanya populasi hama kepinding tanah pada pertanaman padi sawah di Sulawesi Utara adalah Minahasa Selatan, Minahasa Tenggara, dan Bolaang Mongondow. Hal ini menunjukkan bahwa hama kepinding tanah sesuai perkembangannya pada daerah dataran rendah. Hama kepinding banyak ditemukan pada daerah sawah lebak atau pasang surut yang kondisinya selalu tergenang air, dengan kelembaban tinggi (Kartohardjono dkk., 2009), Krebs (1978) menyatakan bahwa sebaran geografik suatu organisme termasuk serangga hama kepinding tanah dibatasi oleh faktor-faktor fisik seperti suhu, kelembaban, air, cahaya dan habitatnya. Mungkin salah satu faktor penentu belum ditemukan adanya hama kepinding tanah di Kabupaten Minahasa adalah ketinggian tempat. Faktor ketinggian tempat adanya kaitannya suhu dan kelembaban dalam suatu wialyah. Sudah tentu suhu yang ada di daerah dataran tinggi menjadi rendah, sedangkan dataran rendah suhu menjadi tinggi yang sesuai bagi hama kepinding tanah. Terindikasi bahwa kepinding tanah hanya ditemukan sampai pada daerah dataran rendah dengan ketinggian tempat sekitar $200 \mathrm{~m} \mathrm{dpl}$, sedangkan wilayah ketinggian tempat di atas $600 \mathrm{~m}$ dpl belum ditemukan populasi hama kepinding yakni Kabupaten Minahasa. Dalam penelitian untuk wilayah ketinggian tempat sekitar $200 \mathrm{~m}$ dpl terdapat Kabupaten Minahasa Tenggara, dan wilyah ini ditemukan populasi hama kepinding tanah. 


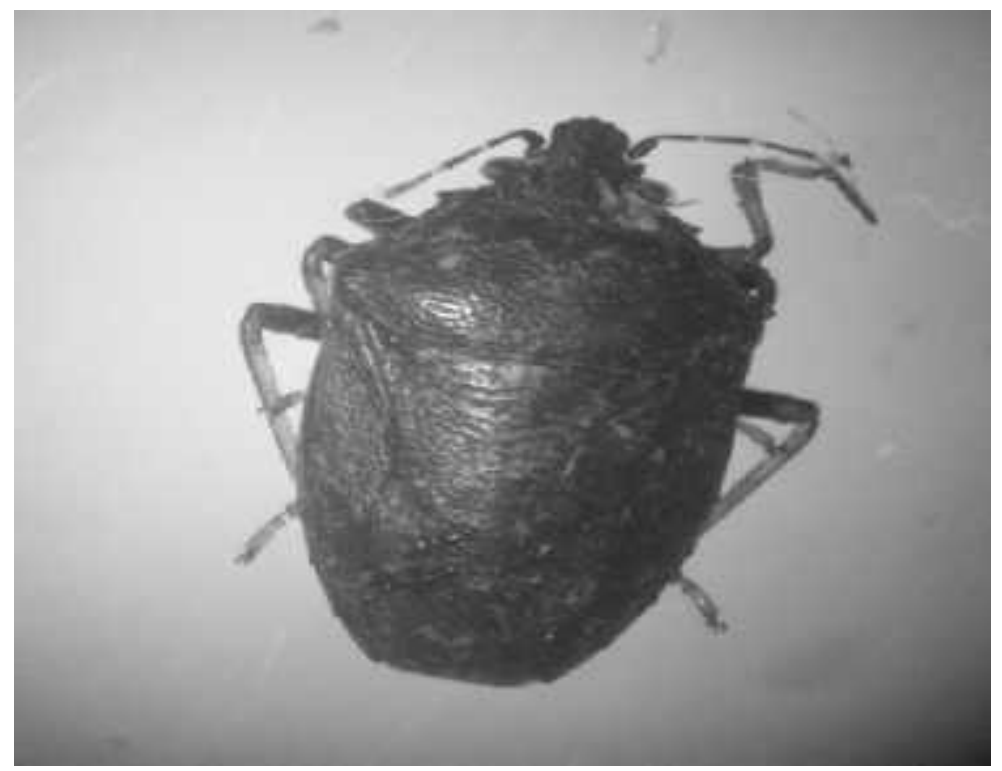

Gambar 1. Morfologi Kepinding Tanah S. coarctata

(Figure 1. Soil Morphology Bedbug S. coarctata)

Di Sulawesi Utara, hama kepinding tanah mulai muncul pada pertanaman padi sawah diperkirakan pada tahun 2006 di Minahasa Utara, kemudian menyebar pada tanaman padi sawah di Minahasa Selatan, Tenggara, dan Bolaang Mongondow. Hasil wawancara 30 petani padi sawah di masing-masing wilayah berbeda kemunculan hama kepinding tanah pada pertanaman padi sawah. Kabupaten Minahasa Selatan hama ini muncul pada tahun 2006, sedangkan Bolaang Mongondow dan minahasa Tenggara pada tahun 2008. Sembel dkk. (2000) melaporkan bahwa hasil pemantauan di lapangan belum ditemukan populasi hama kepinding tanah yang menyerang tanaman padi sawah di Sulawesi Utara.

\section{Populasi Hama Kepinding Tanah}

Populasi hama kepinding tanah yang ditemukan pada masing-masing lokasi pengambilan contoh berbeda. Kepadatan populasi hama kepinding tanah masing-masing wilayah pengambilan contoh dapat diikuti pada Tabel 1.

Data pada tabel 1 menunjukkan bahwa kepadatan populasi hama kepinding tanah tertinggi ditemukan di wilayah Bolaang Mongondow, kemudian diikuti Minahasa Selatan, dan Tenggara. Populasi hama kepinding menjadi tinggi di Bolaang Mongondow sudah tentu banyak faktor yang mempengaruhinya di antaranya iklim, aplikasi insektisida dan musuh alami. Hasil wawancara dengan beberapa petani sawah di Bolaang Mongondow bahwa sebagian besar petani mencampur beberapa jenis insektisida untuk mengendalikan berbagai hama tanaman padi sawah termasuk kepinding tanah. Sedangkan di wilayah Minahasa Selatan dan Minahasa Tenggara sangat jarang petani mencampur jenis insektisida. Adanya campuran beberapa jenis insektisida dapat mempercepat terjadi resistensi hama dan terjadi resurgensi. Bila hama telah terjadi resisten terhadap insektisida biasanya populasi hama kepinding tanah tidak turun secara drastis, bila dilakukan aplikasi dengan insektisida, tetapi terjadi peningkatan populasi. Aplikasi insektisida dapat menyebabkan organisme lain terbunuh, sehingga tidak terjadi kompetisi dalam ruang maupun makanan pada ekosistem tanaman padi sawah, dan menyebabkan populasi kepinding dapat meningkat. Selain itu pula faktor iklim yang mungkin mendukung perkembangan populasi hama kepinding tanah di setiap wilayah. Diduga iklim di Bolaang Mongondow sesuai bagi perkembangan populasi hama kepinding tanah.

Pengambilan contoh hama kepinding tanah dengan jaring serangga serta pengamatan langsung pada rumpun tanaman padi sawah belum ditemukan hama kepinding tanah yang menyerang pada tanaman padi sawah di Kabupaten Minahasa. 
Tabel 1. Populasi Hama Kepinding Tanah Pada Tanaman Padi Sawah

(Table 1. Land of the Bedbug Pest Populations Rice Plants)

\begin{tabular}{lc}
\hline \multicolumn{1}{c}{ Lokasi } & Populasi/20 kali ayunan \\
\hline Kabupaten Minahasa & 0 \\
Kabupaten Minahasa Tenggara & 0,67 individu \\
Kabuoaten Minahasa Selatan & 10,33 individu \\
Kabupaten Bolaang Mongondow & 14,67 individu \\
\hline
\end{tabular}

Hama kepinding tanah merupakan salah satu hama penting pada daerah dataran rendah (Catinding and Kong, 2007; Kartohardjono dkk., 2009), Price (1983) mengemukakan bahwa penyebaran serangga hama sangat dipengaruhi oleh keadaan iklim pada tempat tersebut. Belum ditemukan hama kepinding tanah di Minahasa mungkin dipengaruhi oleh suhu, dimana daerah dataran rendah suhunya lebih tinggi dari dataran tinggi.

\section{Musuh-Musuh Alami}

Dari hasil pengambilan contoh dengan jaring serangga pada tanaman padi sawah telah ditemukan 8 jenis musuh alami terdiri dari 1 jenis parasitoid dan 7 jenis predator. Jenis parasitoid yang ditemukan memarasit telur kepinding tanah di Sulawesi Utara yakni Telenomus sp. Parasitoid Telenomus sp merupakan parasitoid yang memarasit telur hama kepinding tanah (Anonim, 2009; Catinding and Kong, 2007). Catinding and Kong (2007) melaporkan bahwa terdapat 4 spesies Telenomus sp yang memarasit telur hama kepinding tanah. Masing-masing spesies parasitoid Telenomus sp berbeda terhadap inang dari hama kepinding. Hasil pengambilan contoh pada tanaman padi sawah populasi Telenomus sp sangat rendah pada masing-masing wilayah dapat dilihat pada Tabel 2. Aplikasi insektisida yang sering dilakukan dan mencampur beberapa jenis insektisida menyebabkan populasi parasitoid menjadi rendah seperti Bolaang Mongondow dan Minahasa Selatan.

Jenis predator yang ditemukan di Sulawesi Utara sebanyak 7 jenis. Setiap predator memiliki peranan yang berbeda pada masing-masing stadia hama kepinding (Tabel 2). Micraspis crocea hanya memangsai telur dan nimfa, sedangkan Methioche sp hanya memangsai pada salah satu inang kepin- ding tanah yakni telur. Predator yang memiliki inang yang luas dalam memangsai semua stadia hama kepinding tanah adalah golongan laba-laba seperti Tetragntha sp. (Catinding and Kong, 2007). Terdapat pula predator yang berpontensi mengendalikan hama kepinding tanah belum ditemukan Bolaang Mongondow dan Minahasa Selatan yakni Chilomenes sp, predator tersebut hanya ditemukan di Minahasa yang populasi kepinding tanah belum ditemukan di wilayah tersebut.

Dari data pada tabel 2 menunjukkan bahwa variasi musuh alami di Bolaang Mongondow sangat rendah jika dibandingkan dengan Minahasa Selatan dan Minahasa Tenggara. Jumlah species musuh alami yang ditemukan di Bolaang Mongondow hanya 4 species, sedangkan Minahasa Selatan dan Minahasa Tenggara masing-masing 6 jenis. Dengan kurangnya variasi musuh alami mungkin menyebabkan populasi hama kepinding tanah di Bolaang Mongondow tergolong tinggi. Spesies musuh-musuh alami tidak menyebar pada pertanaman padi sawah di beberapa wilayah Kabupaten, dan yang menyebar merata di 4 Kabupaten, yakni Telenomus sp, Tetragnatha sp, dan Oxyopes sp. Predator Micraspis crocea hanya ditemukan di Minahasa Selatan dan Minahasa, demikian pula Chilomenes sp hanya ditemukan di Kabupaten Minahasa.

Selama penelitian ini berlangsung belum ditemukan cendawan patogen yang menyerang stadia hama kepinding tanah. Diduga cendawan entomopatogen ada di Sulawesi Utara asalkan pengambilan data hama kepinding tanah diperluas dan dilakukan secara kontinu. Selain insektisida yang dapat menurunkan populasi hama kepinding tanah, alternatif yang dapat ditempu untuk menekan populasi adalah cendawan patogen. 
Tabel 2. Jenis dan Populasi Musuh-musuh Alami S. coarctata Yang Ditemukan Pada Tanaman Padi Sawah Di Sulawesi Utara.

(Table 2. Population Type and Natural Enemies of S. coarctata Found On The Rice Plant In North Sulawesi)

\begin{tabular}{lllcccc}
\multirow{2}{*}{ No. } & \multirow{2}{*}{ Musuh Alami } & \multirow{2}{*}{ Peranan } & \multicolumn{4}{c}{ Lokasi / Jumlah } \\
\cline { 4 - 7 } & & Pab. Minsel & Kab. Minahasa & Kab. Mitra & Kab. Bolmong \\
\hline 1. & Telenomus sp & Parasitoid & 7 & 10 & 5 & 4 \\
2. & Micraspis crocea & Predator & 1 & 2 & 0 & 0 \\
3. & Methioche sp & Predator & 1 & 4 & 2 & 0 \\
4. & Anaxipha sp & Predator & 0 & 3 & 2 & 1 \\
5. & Tetragnatha sp & Predator & 12 & 18 & 9 & 8 \\
6. & Oxyopes javanus & Predator & 1 & 5 & 3 & 1 \\
7. & Lycosa sp & predator & 1 & 0 & 2 & 0 \\
8. & Chilomenes sp & predator & 0 & 4 & 0 & 0 \\
\hline
\end{tabular}

\section{KESIMPULAN}

Hama kepinding tanah yang menyerang tanaman padi sawah di Sulawesi Utara adalah $S$. coarctata.

Hama kepinding tanah hanya menyebar pada daerah dataran rendah, sedangkan dataran tinggi belum ditemukan hama kepinding tanah di Minahasa, kecuali daerah yang ketinggian kurang lebih $200 \mathrm{~m}$ dpl. Populasi kepinding tanah tertinggi ditemukan Bolaang Mongondow 14,67 individu/ 20 ayunan ganda, Minahasa Selatan 10,33 individu /20 ayunan ganda dan Minahasa Tenggara 0,67 individu/20 ayunan ganda.

Dalam kegiatan ini telah ditemukan 8 jenis musuh alami yang terdiri 1 jenis parasitoid dan 7 predator. Jumlah jenis musuh alami tertinggi di Minahasa, kemudian diikuti Minahasa Selatan dan paling rendah adalah Bolaang Mongondow.

\section{DAFTAR PUSTAKA}

Anonim, 2005. Masalah Lapang Hama, Penyakit dan Hara pada Padi. Kerjsama BPTP dengan IRRI, Bogor.

2009. Rice Black Bungs, as thes Pesr of Rice. Internastional Rice Research Intitute, P.O. Box 933, Manila Philippines.

2010. Pengendalian Hama Dan Penyakit Utama Tanaman Padi Mendukung IP Padi 400. http://riau.litbang.deptan.go.id/ind/ images/stories/PDF/hapen.pdf

, 2011. Indonesia dapat Tambahan Impor beras, Jakarta. http://internasional. kompas.com/read/2011/11/10/22345955/l ndonesia.Dapat.Tambahan.Impor.Beras.

Baehaki, S.E. 1992. Berbagai Hama Serangga Tanaman Padi. Penerbit Angkasa Bandung.

Catinding, Josie L. A and Kong. L Heong, 2007. A Review of the four important alien invasive species on rice and mango in the Philippines. Entomology anf Plant Pathology Division, linternasional Rice Research Institute, Manila. http://www.nhm.ac.uk/ research-curation/staff-directory/ entomology/a-polaszek/index.html

Dale. 1994. Insect Pest of the Rice Plant their Biology dan Ecology in E. H Heinrichs Biology and Managemnet of Rice lbsect. IRRI.

DeBach, P. 1964. Succes, Trends and Future Possibities. In biological control of insect pest and weeds. Ed.by P. DeBach. Reinhold pub, crop.

Harahap, Idam, Sakti dan Tjahjono. 2003. Pengendalian Hama Penyakit Padi. Penerbit Swadaya.

Kalshoven, L.G.E. 1981. The Pests of Crops In Indonesia. PT. Ichtiar Baru Van Hoeve. Jakarta.

Kartohardjono, A., Denan Kartoseputro dan Tatang Surjana. 2008. Hama Padi dan Potensial dan Pengendalian. Balai Besar Penelitian Tanaman Padi. Bogor.

Krebs, C J. 1978. Ecology The Experimental Analysis of Distribution and Abundance, Second Edition. Harper \& Row Publ., NewYork etc. 
Price, P.W. 1985. Insect Ecology. John Wiley \& Sons, New York.

Sembel, D.T., J. Rimbing, M. Ratulangi, M. Meray. 2000. Pemantauan dan Peramalan Organisme Pengganggu Tanaman Pangan di Sulawesi Utara. Fakultas Pertanian Unsrat Manado.

Soemartono, Bahrin Samad dan Hardjono, R. 1984.

Bercocok Tanaman Padi. C.V. Yasaguna, Jakarta.
Torres Marrk Anthony, J., Geoffrey Reuel Quinaquin Yañez, and Cesar G. Demayo. 2010 Image Analysis of Intra-Population Variability in a Non-Outbreak Population of the Rice Black Bug Scotinophara sp. from Tacurong,Sultan Kudarat, Philippines. cgdemayo@gmail.com. 
